\title{
The effect of increased unplanned surgical admissions at a 12 bed critical care unit
}

\author{
NT Nelligan ${ }^{1,2^{*}}$, A Claxton ${ }^{2,3}$, D Dutta ${ }^{2}$ \\ From ESICM LIVES 2015 \\ Berlin, Germany. 3-7 October 2015
}

\section{Introduction}

Unplanned surgical admissions to critical care are indicative of poor outcome in surgical patients [1]. There has been an increase in the number of unplanned admissions to critical care units, which impacts on the allocation of resources, affecting mortality [2]. The hospital where this study took place has seen a doubling of admissions in the last 5 years [3]. A large proportion appeared to be surgically related, prompting a review if outcomes have been jeopardised by the increased strain.

\section{Objectives}

To establish a trend in admissions by month, over 6 months for unplanned surgical admissions to a London fringe hospital \& to determine:

- Mortality rates for the unplanned admissions; compare to previous figures in 2008 and the Intensive Care National Audit \& Research Centre (ICNARC) 2012 report.

- Mortality while on critical care, mortality from discharge to ward \& discharge from hospital.

- Length of stay \& APACHE II scores by outcome for unplanned surgical admissions.

- Volume of patients by speciality \& survival to discharge from hospital by surgical speciality.

\section{Methods}

This is a retrospective analysis of 142 unplanned surgical admissions over 6 months, from $1^{\text {st }}$ July- $31^{\text {st }}$ December 2013, in a London fringe hospital with a 12 bed critical care unit.

A database was developed on excel using coded data \& contained the breakdown of each admission, expected outcome predicted by APACHE II score, outcomes including mortality on ITU/HDU, mortality after discharge to ward

\footnotetext{
${ }^{1}$ The Royal London Hospital, Barts Health Trust, London, United Kingdom
} Full list of author information is available at the end of the article
\& the length of stay by outcome for each of the admissions. The ICNARC 2012 data on similar sized units was analysed \& the 2008 study from the same trust reviewed. We compared to ICNARC data \& the local results from 2008 to assess how the unit is performing regarding patient outcomes \& to see what, if any, changes had occurred since 2008.

\section{Results}

\section{Conclusions}

Despite an increased demand, the overall outcomes compare favourably with national standards, \& previous figures from 2008. Currently patient outcome is not jeopardised by the increased demand on the service. However, if the trend of increasing critical care admissions (planned or unplanned) is to continue at this rate the evidence suggests that good outcomes are unlikely to remain [2].The study also reveals the largest contributing speciality to unplanned admissions was general surgery \& we noted a curious trending of admissions in October/November, which warrants further analysis.

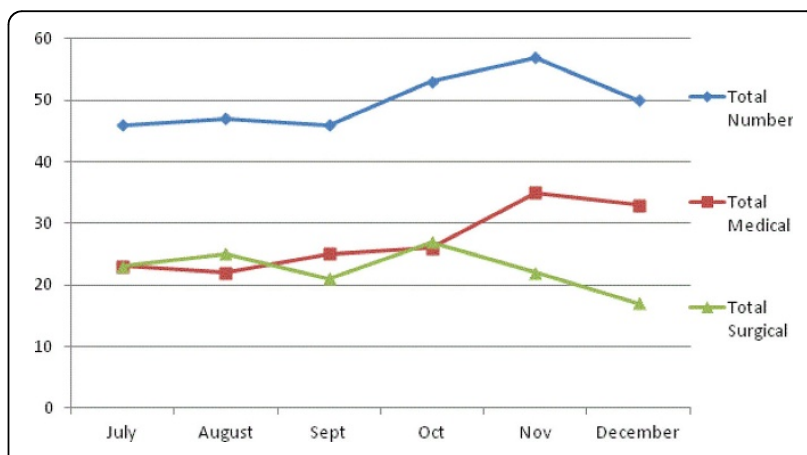

Figure 1 Trend of admission numbers for study period. 


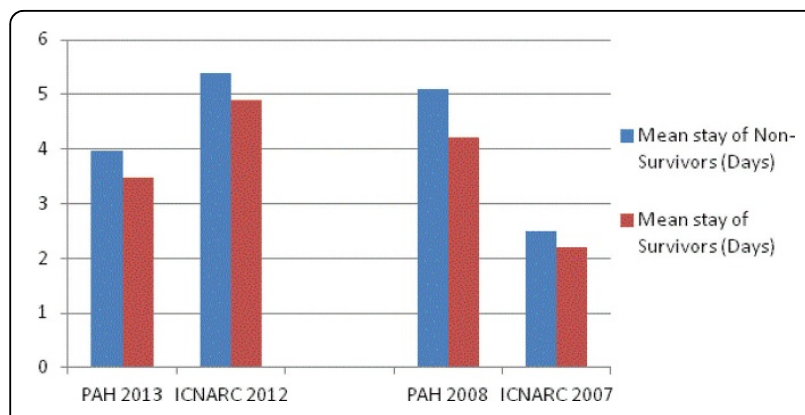

Figure 2 Length of stay by Outcome compared to ICNARC 2012.

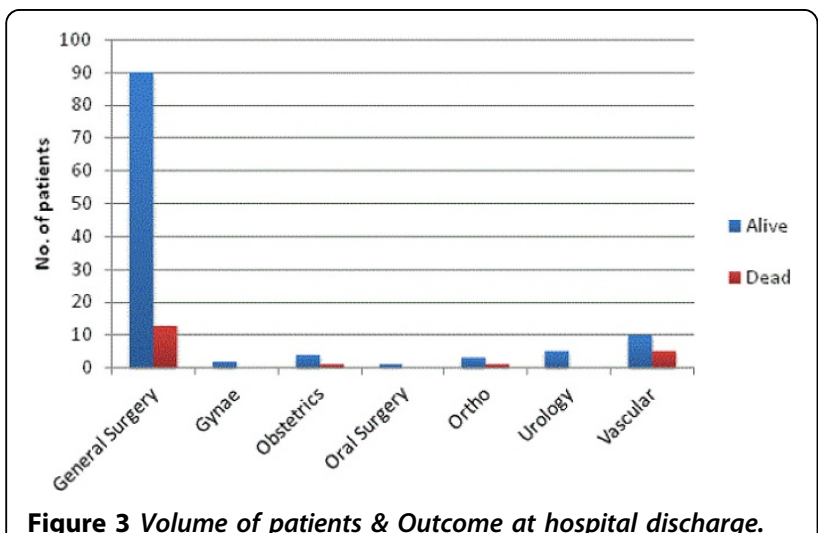

Figure 3 Volume of patients \& Outcome at hospital discharge.

Table 1. APACHE II scores

\begin{tabular}{ll}
\hline MEAN APACHE $\|$ & 15 \\
\hline MODE APACHE $\|$ & 17 \\
\hline RANGE OF VALUES & $2-43$ \\
\hline Expected Mortality based on Mean & $25 \%$ \\
\hline
\end{tabular}

Table 2. Unplanned surgical admissions Mortality Rate (\%)

\begin{tabular}{ll}
\hline Mortality rate 1 st July-31st Dec 2013 & $8.89 \%$ \\
\hline ICNARC 2012 mortality & $11.9 \%$ \\
\hline
\end{tabular}

Table 3. \% unplanned admissions compared to 2008 \& ICNARC

$\%$ of total unplanned admissions that were surgical (In study $45 \%$ period)

\% of total unplanned admissions that were surgical (2008 data) $\quad 26 \%$

National figures - ICNARC $2012 \quad 17.8 \%$

\section{Authors' details}

${ }^{1}$ The Royal London Hospital, Barts Health Trust, London, United Kingdom. ${ }^{2}$ The Princess Alexandra Hospital Trust, Anaesthetics and Critical Care, Harlow, United Kingdom. ${ }^{3}$ South Warwickshire Foundation Trust, Warwick, United Kingdom.

Published: 1 October 2015

\section{References}

1. Haller G, Myles PS, Langley M, Stoelwinder J, McNeil J: Assessment of an unplanned admission to the intensive care unit as a global safety indicator in surgical patients. Anaesth Intensive Care 2008, 36(2):190-200.

2. West E, Barron DN, Harrison D, Rafferty AM, Rowan K, Sanderson C: Nurse staffing, medical staffing \& mortality in Intensive Care: An observational study. Int J Nurs Stud 2014, 51(5):781-879.

3. The P.A.H. NHS trust ICNARC Report; 2008:, Accessed in Hardcopy 23rd Feb 2014.

doi:10.1186/2197-425X-3-S1-A534

Cite this article as: Nelligan et al:: The effect of increased unplanned surgical admissions at a 12 bed critical care unit. Intensive Care Medicine Experimental 2015 3(Suppl 1):A534.

\section{Submit your manuscript to a SpringerOpen ${ }^{\circ}$ journal and benefit from:}

- Convenient online submission

- Rigorous peer review

- Immediate publication on acceptance

- Open access: articles freely available online

- High visibility within the field

- Retaining the copyright to your article

Submit your next manuscript at springeropen.com 